\title{
Antifungal peptides produced by Bacillus subtilis for the biological control of aflatoxin contamination
}

\author{
Makoto ONO* and Norio KIMURA* \\ 小野 誠*，木村宣夫*: Bacillus subtilis が生産するアフラトキシン産 \\ 生菌生育阻害物質の単離・同定
}

\begin{abstract}
Summary
Iturin A, antifungal lipopeptide reported by Peypoux and Isogai, was isolated from submerged culture of Bacillus subtilis $\mathrm{NK} 330$ and its growth inhibitory activity toward aflatoxigenic fungus $A$. parasiticus NRRL 2999 was investigated. At 50 ppm of iturin A in the medium, the toxin production was completely inhibited while the growth of $A$. parasiticus was partially restricted. In contrast, the same amount of cycloheximide showed no significant influence on the toxin production by this fungus.
\end{abstract}

Aflatoxins (AF) are secondary metabolites produced by $A$. flavus and A. parasiticus. They are potent hepatotoxins and carcinogens affecting wide variety of animal species ${ }^{1}$. Many substances, including pesticides ${ }^{2,8}$, spice $^{4)}$ and extract of plants ${ }^{5)}$, were screened for the prevention of AF contamination in foods and feeds. Some microorganisms were also tested for the same purpose. $\mathrm{Cuero}^{6)}$ and $\mathrm{Wicklow}^{7)}$ have reported the influences of various microorganisms on the growth and the toxin production of aflatoxigenic fungi, but in all cases, practical inhibiting potency has not been feasible. In the course of search for the potent antagonist toward Aspergilli, a strain of B. subtilis named NK 330 found to be markedly inhibited the growth and the AF production of $A$. flavus and $A$. parasiticus ${ }^{8)}$. In the following, the isolation and the identification of this antifungal substance is described.

\section{Materials and Methods}

Microorganisms Aspergillus flavus strain NRRL 3357 and A. parastiticus strain NRRL 2999 were used for monitoring antifungal activity. Bacillus subtilis strain NK 330 was isolated from Japanese soil ${ }^{8)}$.

Reagent The specimen of iturin $\mathrm{A}^{9)}$ was kindly supplied by F. Peypoux of Claude Bernard University, France. Cycloheximide was purchased from Nacalai Tesque Co., Japan.

Media Potato-dextrose agar was used for the stock culture of aflatoxigenic fungi. For the assay of antifungal activity, serial plate dilutions of testing samples were made by potatodextrose agar (Difco).

Spectral analysis FAB-MASS: JMS-DX 303 (JEOL). ${ }^{1} \mathrm{H} \cdot \mathrm{NMR}$ : Brucker AM 600 . The

* Research Institute, Morinaga \& Co., Ltd. (2-1-1, Shimosueyoshi, Tsurumi-ku, Yokohama 230).

森永製菓(研究所（干230 横浜市鶴見区下末吉2-1-1） 
chemical shift was determined by reflecting to an internal standard of tetramethylsilane.

Bioassay Serial plate dilution method was used for the assay of growth and AF production of $A$. parasiticus NRRL 2999. Test solution was sterilized by filtration and added to autoclaved PDA under $60^{\circ} \mathrm{C}$. After the agar was set and surface was dried, one drop of spore suspension $\left(2 \times 10^{6}\right.$ spores $\left./ \mathrm{ml}\right)$ of $A$. parasiticus was inoculated at the center of the plate (90 mm I.D.) and incubated at $25^{\circ} \mathrm{C}$ for 7 days. The diameter of colony was measured and AF was analyzed with HPLC according to the authentic method ${ }^{10)}$.

Production and purification of the active substance B. subtilis NK 330 was preincubated in potato-dextrose medium $\left(\mathrm{pH} \mathrm{6.8)}\right.$ for 24 hours in shake culture $\left(100\right.$ r.p.m., $\left.30^{\circ} \mathrm{C}\right)$. A $50 \mathrm{ml}$ of this culture was used to inoculate $10 \mathrm{~L}$-fermenter containing $7 \mathrm{~L}$ of protato-dextrose medium ( $\mathrm{pH}$ 6.8). Submerged culture was performed at $30^{\circ} \mathrm{C}$, under stirring (300 r.p.m.) and aeration $(2 \mathrm{~L} / \mathrm{min}$ ) for 3 days. FS-F-20 (Dow Chem. Co.) was used as anti-form agent. The broth was centrifuged to eliminate cell bodies. The supernatant was concentrated to $300 \mathrm{ml}$ with rotary evaporator. Then, $1.2 \mathrm{~L}$ of ethanol was added to the concentrated supernatant and stirred vigorously for several hours. The precipitated impurities were removed by centrifugation and thoroughly extracted twice with $1.5 \mathrm{~L}$ of $80 \%$ ethanol. The supernatant and the extracts were combined and evaporated to dryness. The residue was dissolved with $500 \mathrm{ml}$ of deionized water. This solution was acidified to $\mathrm{pH} 3.0$ with conc. $\mathrm{HCl}$ to precipitate active substance and left for several hours at $4^{\circ} \mathrm{C}$. The resulting precipitate was collected and dissolved in adequate volume of dil. $\mathrm{NH}_{4} \mathrm{OH}$. This acidification step was repeated until yellowish pigment was removed. Finally obtained precipitate was dissolved in methanol and chromatographed on Sephadex LH-20 column ( $58 \mathrm{~cm} \times 2.6 \mathrm{~cm}$ I.D.) with methanol as eluting solvent. The biologically active fraction was collected and evaporated. This fraction was applied to a silica gel column equilibrated with eluting solvent (silica gel 60, 70-230 mesh, Nacalai Tesque Co., column size $35 \mathrm{~cm} \times 4.7 \mathrm{~cm}$ I.D.). Elution was carried out with ethanol:acetic acid:water $(85: 5: 10, \mathrm{v} / \mathrm{v} / \mathrm{v})$. The collected active fraction was finally purified by using HPLC on a C18 column ( $\mu$-bondasphere C18 $150 \mathrm{~mm}$ $\times 19 \mathrm{~mm}$ I.D., Waters Assoc.). Elution was carried out with a linear gradient of acetonitrile and water, going from 38 to $45 \%$ acetonitrile at $40 \mathrm{~min}$. Total flow rate for the solvent system was $9.0 \mathrm{ml} / \mathrm{min}$.

\section{Results and Discussion}

Six active peaks named F1 to F6 eluted at the retention times of 19.4, 25.9, 27.1, 28.9, 35.9 and $37.2 \mathrm{~min}$ (Fig. 1). About $77 \mathrm{mg}$ of active substances were finally obtained from $7 \mathrm{~L}$ of culture broth. Isolated active substances were soluble in methanol and aqueous ethanol, but practically insoluble in other organic solvent. They were also soluble in alkaline water. Ninhydrin reaction was negative, but after hydrolyzed by $\mathrm{HCl}$, turned positive. Since these properties were closely similar to those of iturin $A^{9,11)}$ isolated fractions were spotted on silica gel TLC plate (silica gel $60 \mathrm{~F} 254$, Merck) with specimen of iturin $\mathrm{A}$ and developed with various solvent systems. Table 1 shows that $R_{f}$ values of all fractions were identical with those of iturin A. Amino acid analyses by TLC of the acid hydrolyzates of six frac- 


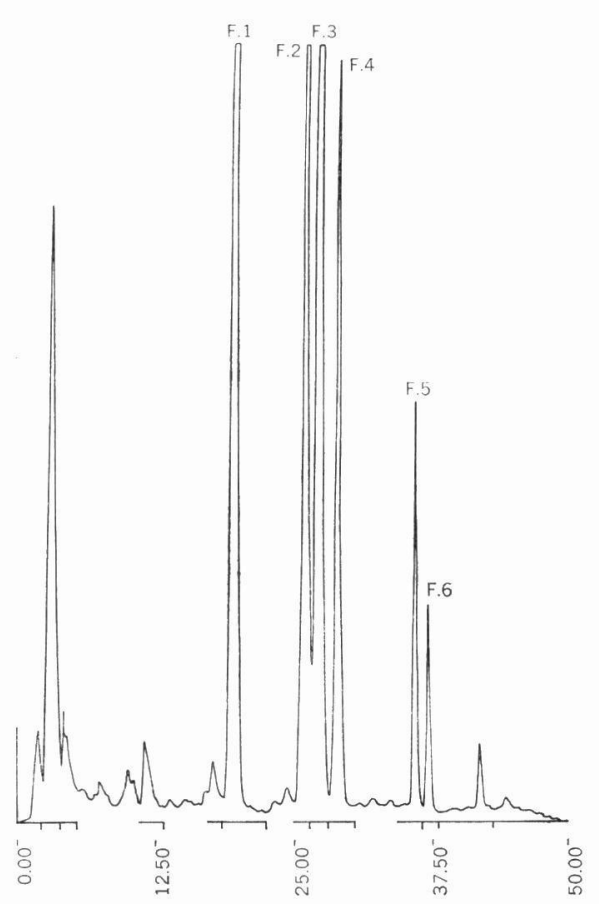

Fig. 1. Chromatograms of $\mathrm{F} 1$ to $\mathrm{F} 6$ on HPLC. The elution profile was monitered at $210 \mathrm{~nm}$.
Table 1. $\mathrm{R}_{f}$ values on silica gel TLC

\begin{tabular}{lcc} 
Solvent system & Iturin $\mathrm{A}$ & $\mathrm{F} 1$ to $\mathrm{F} 6$ \\
\hline $\mathrm{MeOH}$ & 0.58 & 0.58 \\
$\mathrm{EtOH} / \mathrm{AcOH} /$ water & 0.34 & 0.34 \\
$\quad(17: 1: 2)$ & & \\
$\mathrm{n}-\mathrm{PrOH} / \mathrm{AcOH} /$ water & 0.22 & 0.22 \\
$\quad(17: 1: 2)$ & & \\
$\mathrm{n}-\mathrm{PrOH} /$ pyridine/ & 0.29 & 0.29 \\
$\mathrm{AcOH} /$ water & & \\
$\quad(40: 5: 1: 4)$ & &
\end{tabular}

tions showed the presence of aspartic acid, glutamic acid, proline, serine, tryrosine and lipophilic amino acid-like substance, which coincided with those of iturin A. Iturin A consists of eight homologs, iturin A-1 to A-8 and the structures of these homologs (Fig. 2) were established by Isogai ${ }^{11)}$. The mass spectra of F1 (Fig. 3) to F4 were analyzed with FAB-ionization system, which indicate the molecular weights of 1042 for F1 and 1056 for F2 and F3. ${ }^{1} \mathrm{H}-\mathrm{NMR}$ spectrum of F1 (Fig. 4) is identical with that reported for iturin $\mathrm{A}-2^{12)}$, and those of $\mathrm{F} 2$ to $\mathrm{F} 4$ are different only in their chemical shift of $0.9 \mathrm{ppm}$ (Table 2). These variety of the coupling pattern of the signals at $0.9 \mathrm{ppm}$ in ${ }^{1} \mathrm{H}-\mathrm{NMR}$ is due to the differences present in the $\beta$-amino acid portion, and the spectra of $\mathrm{F} 2$ to $\mathrm{F} 4$ coincide with iturin A-3 to A-5 reported by Isogai ${ }^{11)}$. All these data indicate that F1 to F4 were identical

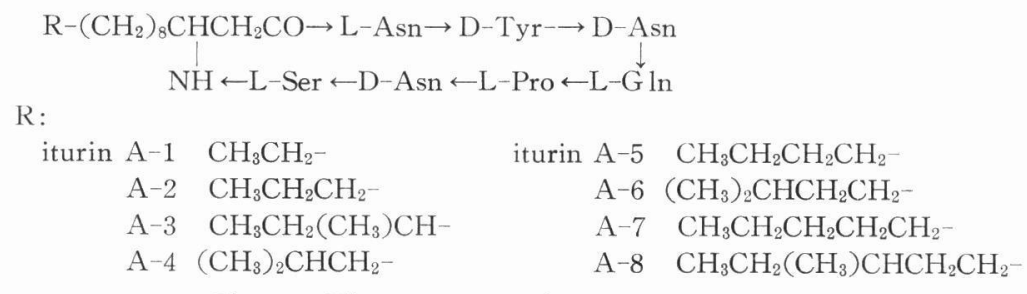

Fig. 2. The structures of iturin $\mathrm{A}-1$ to $\mathrm{A}-8$. 


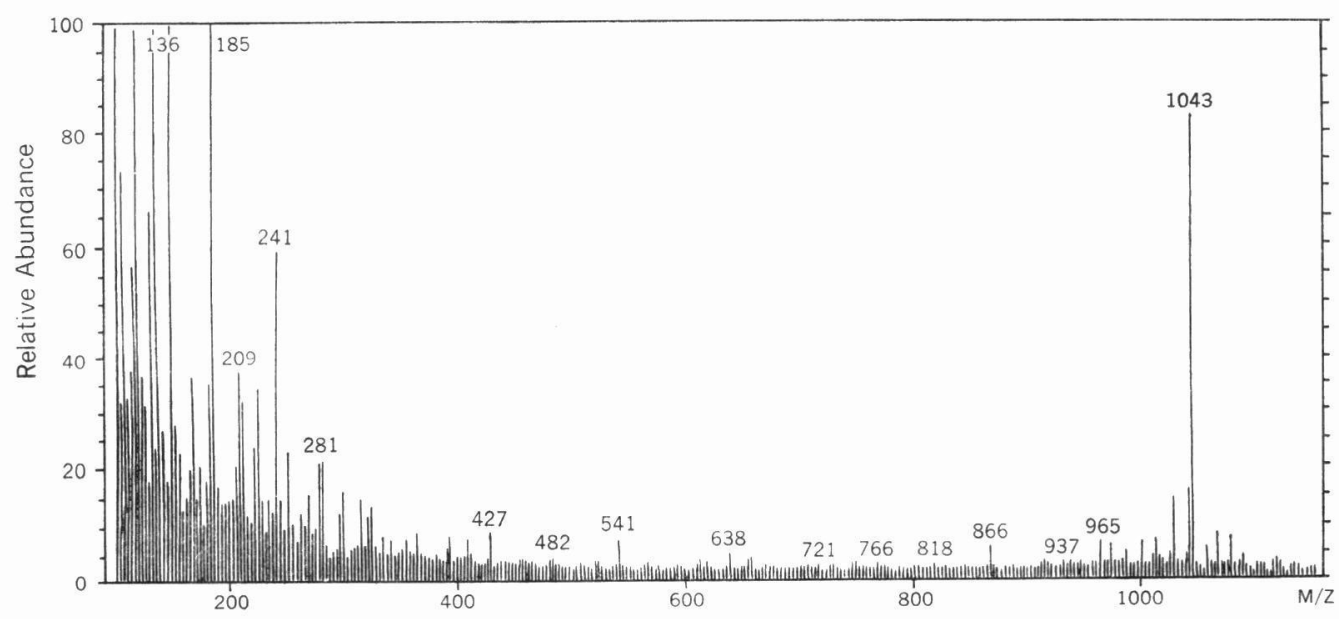

Fig. 3. FAB-MS spectrum of F1. Molecular ion peak at $1043(\mathrm{M}+\mathrm{H})$ was observed. (matrix: glycerine)

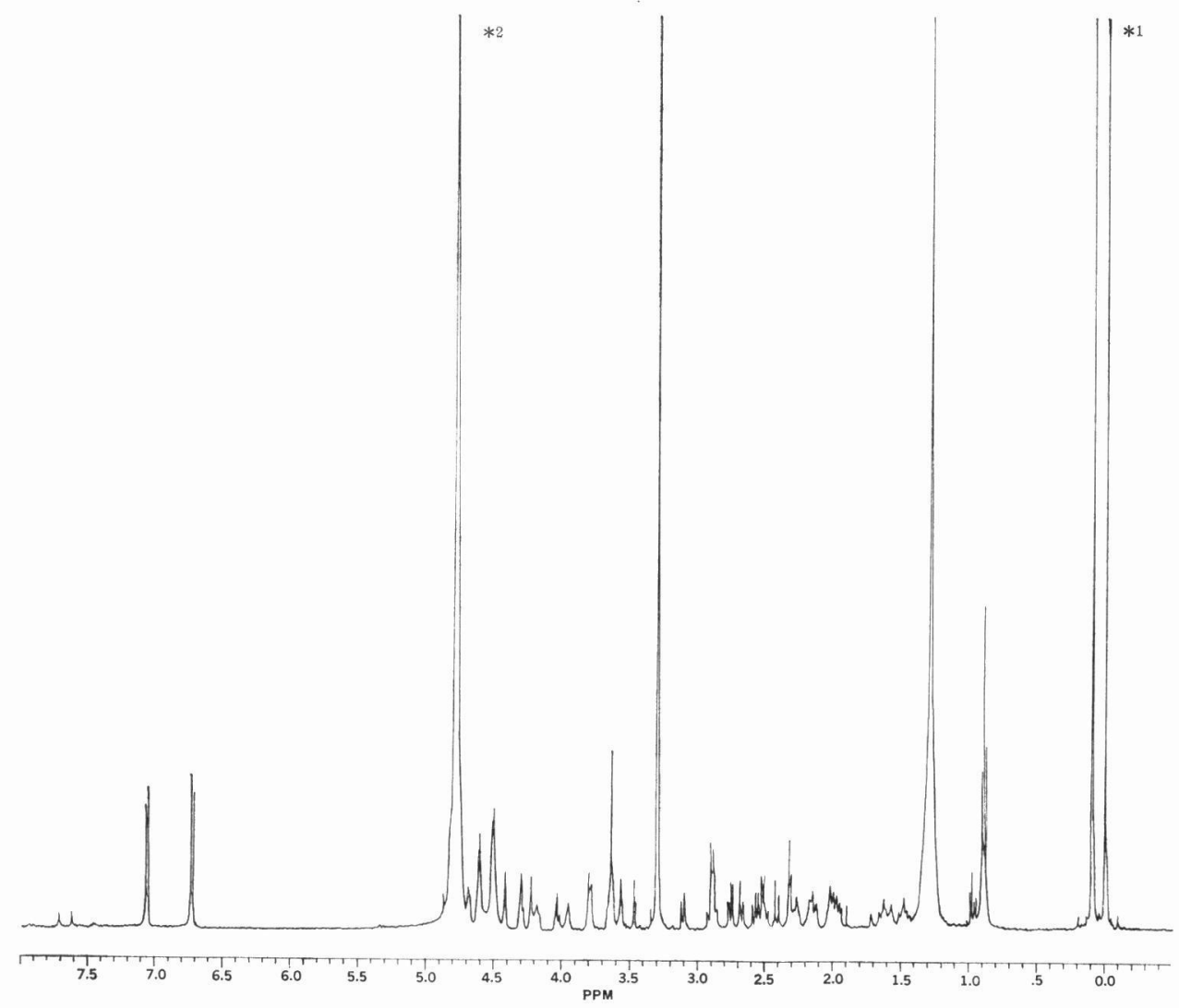

Fig. 4. ${ }^{1} \mathrm{H}-\mathrm{NMR}$ spectrum of $\mathrm{F} 1$. $\mathrm{F} 1$ was dissolved in $\mathrm{CD}_{3} \mathrm{OD}$. ${ }^{* 1}$ : tetramethylsilane; *2: signals derived from methanol $(3.34,4.88 \mathrm{ppm})$. 
Table 2. The coupling pattern of the signals of terminal $\mathrm{CH}_{3}$ of lipophilic $\beta$-amino acid in ${ }^{1} \mathrm{H}-\mathrm{NMR}$

\begin{tabular}{ccccc} 
& $\mathrm{F} 1$ & $\mathrm{~F} 2$ & $\mathrm{~F} 3$ & $\mathrm{~F} 4$ \\
\hline$\delta \mathrm{ppm}\left(\mathrm{CH}_{3}\right)$ & $0.9(3 \mathrm{H}, \mathrm{t})$ & $0.9(6 \mathrm{H}, \mathrm{m})$ & $0.9(6 \mathrm{H}, \mathrm{d})$ & $0.9(3 \mathrm{H}, \mathrm{t})$
\end{tabular}

Table 3. Inhibitory effect of iturin $\mathrm{A}$ and cycloheximide on aflatoxin production by $A$. parasiticus

\begin{tabular}{lcc}
\hline Conc $^{* 1}(\mathrm{ppm})$ & $\begin{array}{c}\text { Diameter of colony } \\
(\mathrm{mm})\end{array}$ & $\mathrm{AF}^{* 2}(\mathrm{ppm})$ \\
\hline control & 60.0 & 2.97 \\
iturin A & & \\
100 & 13.5 & N.D. \\
50 & 46.0 & N.D. \\
25 & 62.5 & 2.31 \\
12.5 & 66.0 & 3.43 \\
cycloheximide*3 & & \\
50 & 50.0 & 1.1 \\
25 & 55.0 & 1.54 \\
12.5 & 58.0 & 2.26 \\
\hline
\end{tabular}

${ }^{* 1}$ : concentration in PDA plate; ${ }^{* 2}: \mathrm{AF} \mathrm{B}_{1}, \mathrm{~B}_{2}, \mathrm{G}_{1}, \mathrm{G}_{2} ;{ }^{* 3}$ : cycloheximide, dissolved in dimethylformamide $(20 \mathrm{mg} / \mathrm{ml})$.

with iturin A-2 to A-5, respectively. From the elution profile and the amino acid constituent, F5 and F6 also seem to be iturin A. But mass spectra and ${ }^{1} \mathrm{H}-\mathrm{NMR}$ spectra of F5 and F6 were failed to obtain because of poor yield of these fractions.

The influence of prepared iturin A on AF production was tested and compared with that of cycloheximide (Table 3). Iturin A showed completely inhibition of AF synthesis by $A$. parasiticus NRRL 2999 after 7 days incubation, though the growth of the fungus was partially inhibited. Cycloheximide was reported to enhance AF production by non-aflatoxigenic strain of $A$. flavus $^{13)}$, but no significant influence on AF synthesis with $A$. parasiticus was detected in this study. Furthermore, iturin A was proved to have more potent antifungal activity toward $A$. parasiticus than cycloheximide. We failed to examine the influence of each isolated fraction on the AF biosynthesis because of poor yield of these fractions. Minimum inhibitory concentration (MIC) of each fraction toward $A$. parasiticus NRRL 2999 was examined up to $150 \mathrm{ppm}$ with plate dilution method on PDA. Even if the concentration of these fractions in PDA plate was $150 \mathrm{ppm}$, these fractions could not completely inhibit the growth of $A$. parasiticus but the diameter of the colony was reduced to $15-20 \%$ of that of control. No significant difference was observed on this reduction of the growth rate among the fractions. Iturin A seemed to have fungistatic activity toward $A$. parasiticus rather than fungicidal activity and this fungistatic nature may result in the inhibition of the AF biosynthesis. Besson ${ }^{14)}$ reported that the site of the action of iturin $\mathrm{A}$ on yeast cell was the cytoplasmic membrane and an important modification of cell permeability was the principle of the action. Iturin $\mathrm{A}$ is considered to have low toxicity and low 
allergenic properties in topical applications ${ }^{15)}$. Recently, iturin A was isolated as active principle in biological control of peach brown rot with B. subtilis ${ }^{12)}$. To apply iturin A for the control of AF contamination, further biological approach is currently on progress.

Acknowledgements: We thank Dr. A. Isogai of the Department of Agricultural Chemistry in the Faculty of Agriculture at the University of Tokyo for the MS and NMR measurement with kindly advice. We thank Dr. F. Peypoux for the gift of iturin A.

\section{References}

1) Newberne, P. M., Butler, W. H.: Cancer Res., 29, 31 (1969).

2) Rao, H.R.G., Harein, P. K.: J. Econ. Entomol., 65, 988 (1972).

3) Dutoton, M. F., Anderson, M. S.: J. Food Prot., 43, 381 (1980).

4) Valcarcel, R., Bennett, J. W., Vitanza, J.: Mycopathologia, 94, 7 (1980).

5) Paster, N., Juven, B. J., Harshemesh, H.: J. Appl. Bacteriol., 64, 293 (1988).

6) Cuero, R. G., Smith, J. E., Lacey, J.: Appl. Environ. Microbiol., 53, 1142 (1987).

7) Wicklow, D. T., Hesseltine, C. W., Shotwell, O. L., Adams, G. L.: Phytopathology, 70, 761 (1980).

8) Kimura, N., Hirano, S.: Agric. Biol. Chem., 52, 1173 (1988).

9) Peypoux, F., Guinaud, M., Michel, G., Delcambe, L., Das, B., Lederer, E.: Biochemistry, 17, 3992 (1978).

10) Ministry of Health and Welfare Notice Kansyoku No. 128 of 1971; Shokukin Eisei Kenkyu (Food Sanitation Research), 21, 564 (1971).

11) Isogai, A., Takayama, S., Murakoshi, S., Suzuki, A.: Tetrahedron Lett., 23, 3065 (1982).

12) Gueldner, R. C., Reilly, C. C., Pusey, P. L., Costello, C. E., Arrendale, R. F., Cox, R. H., Himmelsbach, D. S., Crumley, F. G., Cutley, H. G.: J. Agric. Food Chem., 36, 366 (1988).

13) Schmidt, F. R., Lemke, P. A., Esser, K.: Appl. Microbiol. Bioctechnol., 24, 248 (1986).

14) Besson, F., Peypoux, F., Quentin, M. J., Michel, G.: J. Antibiot., 37, 172 (1984).

15) Delcambe, L., Peypoux, F., Guinand, M., Michel, G.: Rev. Ferment. Ind. Aliment., 31, 147 (1976). 